\title{
風工学における評価に用いる風速の考え方 \\ Wind Speed used for Evaluation in Wind Engineering
}

\author{
南雲 洋介*1 \\ Yosuke NAGUMO \\ 菊本 英紀 ${ }^{* 5}$ \\ Hideki KIKUMOTO
}

\author{
荒木 啓司*2 \\ Keiji ARAKI \\ 木村 吉郎*6
}

Kichiro KIMURA

\author{
赤星 明紀*3 \\ Akinori AKAHOSHI \\ 長谷部 寛*7 \\ Hiroshi HASEBE
}

\author{
田中 英之*4 \\ Hideyuki TANAKA
}

1.はじめに

本稿では, 研究会の活動を通じて議論・整理してきた各 分野での評価に用いる風速の考え方について整理する。 今回取り扱う分野は, 鉄道 (車両の而風性評価), 風環境 評価, 建築物等の耐風設計, 物質の拡散と濃度 (大気污染, 臭気), 橋梁, 遊具・スポーツである。各分野で評価する 事象や目的とその基準, 評価する際に用いる風速の定義, 現在の主な計測・予測方法, それぞれの評価における瞬間 風速に関する課題や最新の動向などについてまとめる。

2. 鉄道〜車両の而風性評価と沿線での強風観測〜

2. 1 評価する事象・目的とその基準

強風下を走行する鉄道車両の走行安全性を確保する観 点から，鉄道沿線での強風発生状況が逐次評価されてい る。強風発生状況を表す指標として, 主に鉄道沿線に配置
された風速計で観測される瞬間風速が用いられており, この瞬間風速と運転規制值とを照らして鉄道車両の運行 が制御（強風時の運転規制）されている ${ }^{1)}$

2. 2 風速指標（平均 or 瞬間）とその平均化時間

鉄道車両の而風性評価や鉄道沿線の強風観測には，瞬 間風速が用いられている。瞬間風速の平均化時間は明確 に定められてはいないが, 国土交通省の指針 ${ }^{2)}$ によると， 最大 3 秒までの移動平均処理を施した風速值で置き換え てよいとされており，併せて瞬間風速を観測する時間間 隔（サンプリング間隔）は 1 秒以下とすることが推奨さ れている。

2.3 現在の主な観測・予測方法

強風の観測は, 主に鉄道浻線に配置された風速計 (規制 用風速計）で常時行われている。国土交通省の指針 2)によ ると，鉄道で使用する風速計に必要な性能は表 1 のとお

\footnotetext{
* 1 東日本旅客鉄道株式会社 JR 東日本研究開発センター安全研究所 研究員 yosuke-nagumo@jreast.co.jp Researcher, Safety Research Laboratory, R\&D Center of JR East Group, East Japan Railway Company

* 2 公益財団法人鉄道総合技術研究所防災技術研究部気象防災 主任研究員 (上級) Chief Researcher, Meteorological Disaster Prevention Group, Railway Technical Research Institute

* 3 株式会社風工学研究所

Wind Engineering Institute Co., Ltd.

* 4 株式会社竹中工務店 技術研究所

Takenaka Research \& Development Institute, Takenaka Corporation

* 5 東京大学生産技術研究所 准教授

Associate Professor, Institute of Industrial Science, The University of Tokyo

* 6 東京理科大学理工学部 教授

Professor, Faculty of Science and Technology, Tokyo University of Science

* 7 日本大学理工学部 准教授

Associate Professor, College of Science and Technology, Nihon University
} 
表 1 鉄道で使用する風速計に必要な性能 2)

\begin{tabular}{|c|c|}
\hline 特性值 & 必要な性能値 \\
\hline 起動風速 & $\begin{array}{l}\text { 警戒あるいは規制を発動する風速を測定する観点からは } 10 \mathrm{~m} / \mathrm{s} \text { で十分。ただし，風速 } 0 \mathrm{~m} / \mathrm{s} \text { が } \\
\text { 一定時間連続したら，風速計が故障したとみな管理方法を採用する際は，起動風速は低い方 } \\
\text { が望ましい。 }\end{array}$ \\
\hline 測定最大風速 & 鉄道が敷設される環境では 60m/s で十分。 \\
\hline 距離定数 & $\begin{array}{l}12 \mathrm{~m} \text { 以下で十分。(気象業務法に基づく検定に合格した場合, 風杯の直径が } 5 \mathrm{~cm} \text { 以下の風杯 } \\
\text { 型風速計を除き距離定数は } 12 \mathrm{~m} \text { 以下である。) }\end{array}$ \\
\hline
\end{tabular}

りである。観測に用いられる風速計の型式については, 風 杯型の利用実績が高い。

強風の予測 (forecast) は, 一部の鉄道会社にて時系列解 析により数分から数十分先の将来風速の最大值を予測し, 強風時の運転規制に用いられている例がある ${ }^{3)}$

\section{4 平均化時間の根拠}

鉄道分野での風の評価に瞬間風速を用いることの根拠 のひとつとして, 1986 年に山陰本線の余部橋梁（鎧〜餘 部間) で発生した列車転覆事故の調査結果 ${ }^{4)}$ から, 鉄道車 両の転覆には瞬間風速が大きく影響寸ることが明らかに なったことが挙げられる。同調查報告によると,「転覆限 界風速以上の横風が車両に作用したときに車両が転覆に 至るまでの空気力の作用時間を評価するため，車両のバ ネ系を無視した剛体モデルについて計算を行った結果, 風速が転覆限界風速を超えると短時間で車両が復元でき なくなることがわかった」とされており，これにより強風 時の運転規制は平均風速ではなく瞬間風速によって行う べきとの見解が示された。また，国土交通省の指針2)にも， 「強風により車両の風上側車輪が浮き上がり, 転覆に至 るまでの時間は極めて短いので, 鉄道における風監視で は，短時間の空気力と密接な関係にあると考えられてい

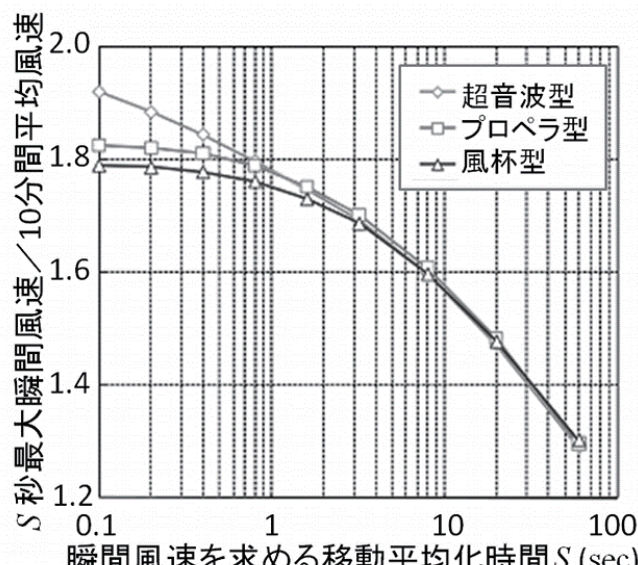

図 1 風速計の違いによる最大瞬間風速の違い5)
る瞬間風速を用いて風の強さを評価するものとする」と の記載がある。

一方, 瞬間風速の平均化時間についてはその根拠が理 論的に解明されているとは言い難い。観測結果を用いた 統計的手法による検討例はいくつか挙げられ，風速計の 違いによる突風率の調査結果5)では, 瞬間風速を求める移 動平均化時間を 3 秒以上にすることで, 風速計の違いに よって運転規制のかかりや寸さが異なるという問題を解 消できるとされている（図 1)。また，鉄道車両に作用す る瞬間空気力を瞬間風速から推定した解析結果 のでは, 3 秒程度の平均化時間で瞬間風速を評価することで，瞬間 空気力の実測值と推定值の比の頻度分布の平均值が 1 と なることが示されている(図2, 参考文献のを一部修正)。 瞬間風速の平均化時間を 3 秒とすることについて, 国土 交通省の指針 ${ }^{2)}$ には明確な根拠は記されていないものの, 上記のような学術的な検討結果はその妥当性を裏付けて いる。

2. 5 鉄道での瞬間風速に関する課題や最新の動向

（1）瞬間風速が有する空間代表性の評価

前述したとおり，鉄道分野で風の評価に瞬間風速を用 いているのは，強風を受けた車両の挙動に由来するもの

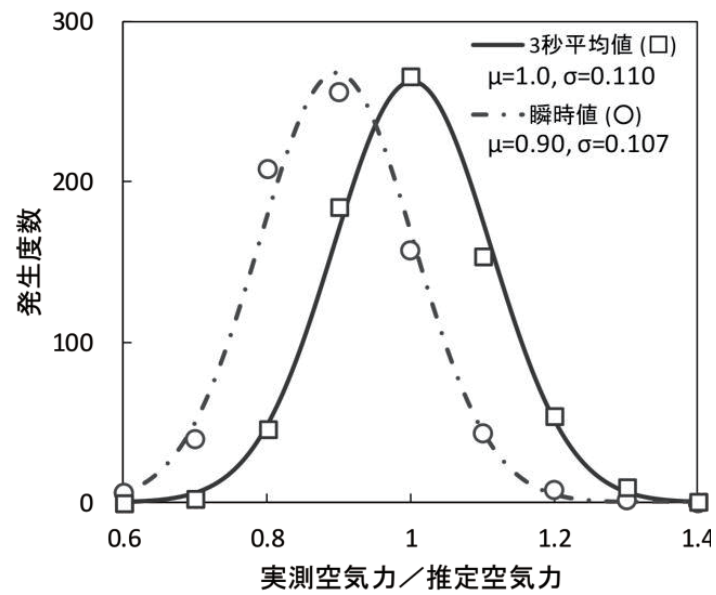

図 2 空気力の実測值と推定值の比の頻度分布 ${ }^{6}$ 
である。現在, 鉄道沿線の強風エリアを包含するように運 転規制区間が設定され，同区間内に配置された風速計で 計測した瞬間風速で運転規制が行われている。数 $\mathrm{km}$ も しくはそれ以上の長さを有するひとつの規制区間の中の, その区間を代表する強風箇所に風速計は設置されており， この風速計で「規制区間内で生じる最も強い風が観測さ れている」ことが安全確保の前提となっている。しかしな がら, 強風をもたら寸気象擾乱の種別や経路とその盛衰, 地形や市街地化などの条件の違い等によって，規制区間 内で最大の風速が風速計の配置地点で常に観測されると は限らず，一つの風速計で観測される瞬間風速が代表で きる空間の広さに関する検討が必要と考えられる。簡易 な 2 地点間の風速変動モデルを用いて, 2 地点間の風速 差を定量的に推定する手法を提案している例》など, 風速 の空間的な相関性に着目した研究例があるが，実際の鉄 道沿線周辺の地形や市街地化の影響を考慮した成果の一 般化が課題といえる。

（2）鉄道沿線の風環境評価に対する CFD 一の期待

前項で述べた瞬間風速と空間代表性の議論とも関連す るが，鉄道沿線の強風監視に用いる風速計の配置や強風 時の運転規制区間の設定をより合理的なものとするため には, 鉄道沿線の風環境, 特に鉄道車両の転覆にとって危 険な風速以上となる瞬間風速の発生のしやすさを評価し ておく必要がある。しかしながら, 日本国内の鉄道の営業 キロは約 $27,800 \mathrm{~km}$ (2020 年3 月末時点) あり, この膨大 な延長を有する鉄道の沿線に，一定間隔で風速計を設置 し, 実観測で得た瞬間風速から沿線の風環境を評するこ とは現実的ではない。また, 特に都市圈を走る鉄道沿線価 では，建物の立て込み具合や強風時に卓越する風向次第 で，実観測される瞬間風速は大きく影響を受けることか ら, 風速計の設置位置を経験的判断ではなく理論的に決 定することの技術的難易度は低くない。

そこで, CFD の活用が考えられる。これまでも，CFD を用いた鉄道沿線での強風発生の予測や評価に関する研 究はいくつか例がある ${ }^{8)}$,9怯。ここれらの研究例では, CFD

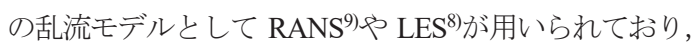
CFD の計算結果は主に基準点（風観測点）に対する風速 比として使用され, 瞬間風速への変換には CFD とは別に 評価された突風率が用いられている。計算機能力の向上 に伴い, LES によるCFD も身近なものとなってきたなか で, CFD の計算結果から瞬間風速相当の風速が直接的に 評価できれば，より効率的に鉄道沿線の風環境評価が行 えることが期待される。鉄道分野における瞬間風速評価 では, 都市圈を対象にした場合, 空間スケールとして運転
規制区間の単位長である一駅間数 $\mathrm{km}$ ，また時間スケール として一駅間の鉄道車両の通過所要時分である数分間が 一つの目安となるが, 既往の研究例 ${ }^{8)}$ ではこのようなス ケールでの瞬間風速評価に適した LES の計算条件設定が 十分に検討されていないことが課題である。今後, 他分野 での LES を用いた瞬間風速評価に関する成果や知見も参 考にしながら, LES を含む CFD を鉄道沿線の瞬間風速評 価により積極的に活用していく必要があると考える。

（3）他機関情報の活用

2005 年に羽越本線の北余目〜砂越間で発生した列車転 覆事故の調查報告書 10)では, 「鉄道事業者はより適切な運 転規制を必要箇所で行うため, 自ら設置した風速計の観 測值以外にも, 気象庁の発表する警報等気象情報の有効 活用を図ることにより，鉄道線路周辺における強風状況 の把握及び監視体制についてより一層の充実を図るべき である」と指摘されている。これを受けて, 気象庁が配信 する気象情報を活用して突風の発生を予測する手法が導

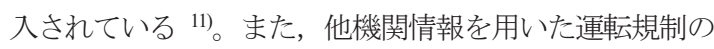
例として, 気象庁や国土交通省のレーダ雨量を活用した 雨量規制が挙げられる ${ }^{12), 13) 。 ~}$

強風時の運転規制としての他機関情報の活用実績はこ れまでに聞いていないが，近年の気象観測網の発達や情 報通信技術の向上に伴い, 今後の活用可能性は考えられ る。一方, 他機関情報を用いる際の留意点として, 先に述 べた空間代表性に加えて, 測器や風速評価方法の違いを 考慮する必要があると考えられる。気象庁のアメダスを 例に挙げると, 風速計には風車型が用いられており, 瞬間 風速の観測方法は2007年より 3 秒平均值が採用されてい る。この例で鉄道とアメダスの観測結果を等価に扱うた めには, 瞬間風速を 3 秒平均值で評価寸る必要がある。 ほかにもデータ通信品質の確保や不通時の対応なども必 要であり, 他機関情報の活用にあたってはこれらを踏ま えた総合的な検討が必要であるといえる。

\section{3. 風環境評価}

3. 1 評価する事象と目的・評価基準について

高層建築物の建設に伴いビル風などの強風の発生頻度 が増加すると, 近隣住民とのトラブルや, 歩行者等の転倒 被害などの風害を生じることがある。そのため, 周辺の風 環境に比較的大きな影響を与えると思われる高層建築物 の建築に際しては, 風洞実験や数值流体解析, 現地観測等 による風環境の調査および評価が行われている。風環境 の評価指標は様々なものが提案されているが，環境影響 評価等の実務においては, 表 2 および表 3 に示寸村上ら 
表 2 村上らによる風環境評価指標

\begin{tabular}{|c|c|c|c|c|c|}
\hline \multirow{2}{*}{\multicolumn{2}{|c|}{ 強風による影響の程度 }} & \multirow[t]{3}{*}{$\begin{array}{c}\text { 対応寸る } \\
\text { 空間用途の例 }\end{array}$} & \multirow{2}{*}{\multicolumn{3}{|c|}{$\begin{array}{c}\text { 評価されるべき強風のレベルと } \\
\text { 評価される超過頻度 }\end{array}$}} \\
\hline & & & & & \\
\hline & & & $10 \mathrm{~m} / \mathrm{s}$ & $15 \mathrm{~m} / \mathrm{s}$ & $20 \mathrm{~m} / \mathrm{s}$ \\
\hline ランク 1 & $\begin{array}{c}\text { もっとも影響を受けやすい } \\
\text { 用途の場所 }\end{array}$ & $\begin{array}{l}\text { 住宅地の商店街 } \\
\text { 屋外のレストラン }\end{array}$ & $\begin{array}{c}10 \% \\
(37 \text { 日) }\end{array}$ & $\begin{array}{l}0.9 \% \\
(3 \text { 日) }\end{array}$ & $\begin{array}{l}0.08 \% \\
(0.3 \text { 日) }\end{array}$ \\
\hline ランク 2 & $\begin{array}{c}\text { 影響を受けやすい } \\
\text { 用途の場所 }\end{array}$ & $\begin{array}{c}\text { 住宅街 } \\
\text { 公園 }\end{array}$ & $\begin{array}{l}22 \% \\
(80 \text { 日) }\end{array}$ & $\begin{array}{l}3.6 \% \\
(13 \text { 日) }\end{array}$ & $\begin{array}{l}0.6 \% \\
(2 \text { 日) }\end{array}$ \\
\hline ランク 3 & $\begin{array}{c}\text { 比較的影響を受けにくい } \\
\text { 用途の場所 }\end{array}$ & 事務所街 & $\begin{array}{c}35 \% \\
(128 \text { 日) }\end{array}$ & $\begin{array}{c}7 \% \\
(26 \text { 日) }\end{array}$ & $\begin{array}{l}1.5 \% \\
(5 \text { 日) }\end{array}$ \\
\hline
\end{tabular}

(注 1) 日最大瞬間風速 : 評価時間 2 3 秒 ここで示寸風速值は，地上 $1.5 \mathrm{~m}$ の定義

(注 2) $\int 10 \mathrm{~m} / \mathrm{s}$--- ごみが舞い上がる。干し物が飛ぶ。

日最大瞬間風速 $\left\{\begin{array}{l}15 \mathrm{~m} / \mathrm{s} \text {--- 立看板, 自転車などが倒れる。歩行困難 } \\ 20 \mathrm{~m} / \mathrm{s} \text {--- 風に吹き飛ばされそうになるなどの現象が確実に発生する。 }\end{array}\right.$

等の現象が確実に発生する。

(注 3) ガストファクター

(地上 $1.5 \mathrm{~m}$, 評価時間 2 3 秒)

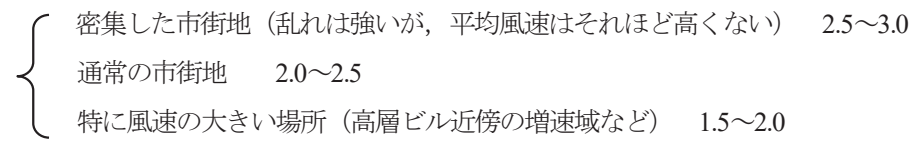

表 3 風工学研究所による風環境評価指標

\begin{tabular}{|c|c|c|c|}
\hline \multirow{2}{*}{ 領域区分 } & \multicolumn{2}{|c|}{$\begin{array}{c}\text { 累積頻度 } 55 \%, 95 \% \text { の } \\
\text { 平均風速 }\end{array}$} & 街並との関係 \\
\cline { 2 - 4 } & $55(\%)$ & $95(\%)$ & \\
\hline 領域 $\mathrm{A}$ & $\leqq 1.2 \mathrm{~m} / \mathrm{s}$ & $\leqq 2.9 \mathrm{~m} / \mathrm{s}$ & 住宅地相当 \\
\hline 領域 B & $\leqq 1.8 \mathrm{~m} / \mathrm{s}$ & $\leqq 4.3 \mathrm{~m} / \mathrm{s}$ & 低中層市街地相当 \\
\hline 領域 C & $\leqq 2.3 \mathrm{~m} / \mathrm{s}$ & $\leqq 5.6 \mathrm{~m} / \mathrm{s}$ & 中高層市街地相当 \\
\hline 領域 D & $>2.3 \mathrm{~m} / \mathrm{s}$ & $>5.6 \mathrm{~m} / \mathrm{s}$ & 強風地域相当 \\
\hline
\end{tabular}

による風環境評価指標 ${ }^{14)}$ と風工学研究所による風環境評

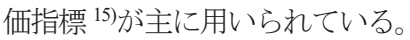

3. 2 評価に用いる風速の定義

（1）評価に用いる風速とその平均化時間

村上らによる風環境評価指標においては, 平均化時間 2 ～3 秒の日最大瞬間風速を基準としており, 風工学研究所 風環境評価指標においては，10 分間の平均風速を基準と している。瞬間風速は平均風速に比べると, 人の風に対す る印象や風害との相関が高いと言われているが 16),17)，後 述するように，計測・予測方法に関する課題がある。

(2) 瞬間風速の平均化時間の根拠について

村上らによる風環境評価指標においては, 前述の通り, 瞬間風速の平均化時間を 2 3 秒としている。同様に瞬間 風速の平均化時間に 2 3 秒を提案している Melbourne ${ }^{18)}$ は, その平均化時間の根拠として, 人間の体感 (応答) と いう観点からは，数秒を平均化時間とした瞬間風速が扱 いやすい点と，2３秒を平均化時間とした瞬間風速が，
ダインス風速計や，より大きめな風杯型風速計によって 記録された最大瞬間風速に概ね対応するという点を述べ ている。村上らについては, 村上らが用いた観測データ収 録システムに関する藤井らの説明 ${ }^{19)}$ によると, 瞬間風速 の平均化時間を 4 秒とすると三杯型風速計の周波数応答 曲線が超音波型風速計の周波数応答曲線と概ね対応する ことや, 瞬間風速の平均化時間として 2 3 秒が一般的で あるということを平均化時間の根拠として述べている。

\section{3 現在の主な計測・予測および観測方法}

風環境の計測・予測には, 主に風洞実験と数值流体解析 が用いられる。実務における風環境調査では, 限られた時 間や予算の中で計測・予測を行うために, 風洞実験におい ては取り扱いの簡便さなどからサーミスタ風速計を用い ることが一般的であり, 数值流体解析においては, 計算負 荷が比較的小さい RANS (Reynolds-Averaged Navier-Stokes) モデルを用いることが一般的である。また, 風環境の現地 観測においては, 機械式風速計 (三杯型風速計や風車型風 速計) が多く用いられてきたが, 乱流中における応答性の 問題 20)が古くから指摘されており，その一方で，以前に 比べて高性能化，低価格化した超音波式風速計が用いら れる例が増加してきている。村上らによる指標を用いて 風環境評価を行う場合, 最大瞬間風速を計測・予測する必 要があるが，サーミスタ風速計を用いた風洞実験や，

RANS モデルを用いた数值流体解析においては，測器や 乱流モデルの特性から，直接瞬間風速を取り扱うことが できないため, 平均風速にガストファクター (最大瞬間風 
速と平均風速の比）を乗じることで得られる最大瞬間風 速を用いることが一般的である。現地観測においては, 機 械式風速計や超音波型風速計から直接瞬間風速を得るこ とができるが, 前述の通り, 測器の応答性には留意する必 要がある。

\section{4 瞬間風速に関わる課題や動向}

前述の通り，実務における風洞実験や数值流体解析に おいて, 村上らによる風環境評価指標を用いる場合, 平均 風速にガストファクターを乗じて最大瞬間風速を用いる ことが一般的であるため，ガストファクターの設定方法 が評価結果に大きな影響を与える。村上らの風環境評価 指標のためのガストファクターを求める式は様々提案さ れており，どの式を用いるかによって評価結果がばらつ いてしまうことが課題として指摘されている。図 3 は, 義江ら ${ }^{21}$ がガストファクターの提案式による差について 示したものである。図3において, $R$ は風速比を, $G F$ は ガストファクターを示し，(5)式は義江らによる提案式を 示している。（5）式と本郷ら 22)の式はほぼ同様の結果と なっている。木梨ら ${ }^{23)}$ の式および西村らの式 $\left.{ }^{24}\right)$ は, $R$ が 約 0.3 よりも小さい範囲において(5)式よりも $G F$ が大き $<, R$ が約 0.3 よりも大きい範囲においては(5)式よりも $G F$ が小さいが, 西村らの式の方が木梨らの式に比べて, その傾向が大きい。

このような背景から, 近年, 風洞実験や数值流体解析に おいて瞬間風速を直接扱えるよう, 検討が進められてい る。風洞実験においては，例えば PIV（Particle Image Velocimetry : 粒子画像流速計) を用いた最大瞬間風速の測

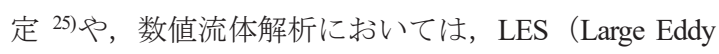
Simulation）を用いて最大瞬間風速を計算する 26,27)といっ た検討が進められており, 未だ実務で活用するには至っ てはいないものの, その有効性について, 以前にも増して 注目されるようになってきている。

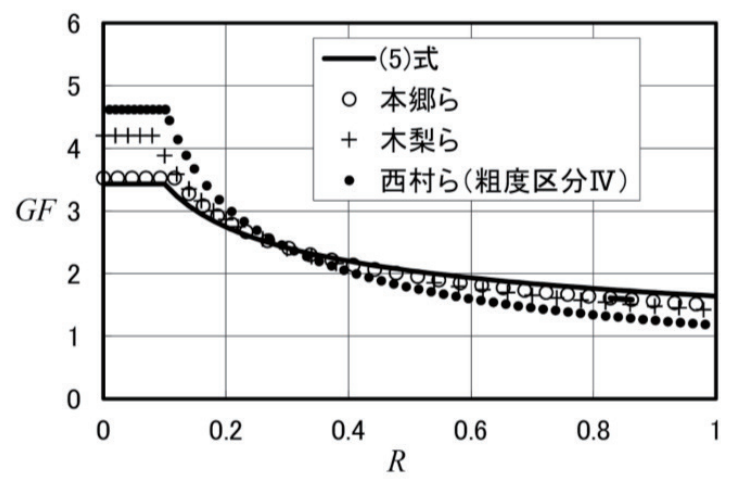

図3 ガストファクターの提案式による差 ${ }^{21)}$

\section{4. 建築物等の耐風設計}

4. 1 評価する事象・目的・基準

建築物の耐風設計では，建築基準法や建築物荷重指針 に示された基準風速 $\mathrm{V}_{0}$ (建築物荷重指針では基本風速 $\mathrm{U}_{0}$ ) を用いて設計風速や設計速度圧が算定される注1)。この設 計速度圧を用いて，建築基準法や建築物荷重指針もしく は風洞実験や数值流体計算によって求めた外圧・風力係 数から構造骨組用風荷重および外装材用風荷重が算定で きる。構造骨組用風荷重は, 柱, 梁などの主要構造部材の 設計に用いるものであり, 外装材用風荷重は外装仕上げ 材およびその下地構造材ならびにそれらの接合部の設計 に用いられる ${ }^{28)}$

建築基準法では，第 1 条に「この法律は，建築物の敷 地, 構造, 設備及び用途に関する最低の基準を定めて, 国 民の生命, 健康及び財産の保護を図り, もつて公共の福祉 の増進に資することを目的とする」とあり ${ }^{29)}$ ，建築基淮 法に基づいて算定される設計速度圧や風荷重は最低基準 を示し, 法的な拘束力があるため, これを下回ることはで きない。一方の建築物荷重指針で算定される設計風速や 風荷重には法的な拘束力はなく, 設計者が設計風速のグ レードを再現期間換算係数によって任意に設定できるた め, 風荷重レベルの選択が可能になっている。

一方, 一般的に使用期間が短く, 解体寸ることが前提で ある仮設構造物は安全対策が安易になりがちであるが, 倒壊等による災害を防止するためには, 設計段階から仮 設構造物に作用する荷重等について十分に検討していく ことが必要である。足場に作用する水平荷重のうち, 評 価・検討する重要な項目の一つに風による荷重があり, 技 術指針が取りまとめられ, 改定されてきている ${ }^{30)}$ 。主な 改定内容としては, メッシュシートを張った足場の風力 係数を明らかにすること, 各地域における基準風速 $\mathrm{V}_{0}$ を 最新のデータにより見直すこと, 各種補正係数等を見直 すこと, 等がある。技術指針にまとめられている資料の目 的は, 風に対寸る足場 (地表面から高さ $100 \mathrm{~m}$ 以下の鋼管 足場等) の安全性を確保するため, 足場に作用する風荷重 の算定方法を明確にすることである。

\section{2 評価する際に用いる風速の定義}

設計風速を求めるときの基本となる風速である基準風 速（基本風速）は，地表面粗度区分 $\Pi$ の地上 $10 \mathrm{~m}$ におけ る平均風速であり, 建築基準法は 50 年, 建築物荷重指針 では 100 年といった再現期待值の違いはあるものの, い ずれの基準でも 10 分間平均值である。この平均化時間時

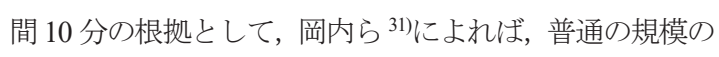
構造物の耐風性が問題になるとき, 気象学における時間 
的，空間的な広がりを体系化した表 4 の分類を参考に， 最も小さい規模である micro-scale の大気乱流の特性を把 握することになるため, 平均化のための時間として 10 分 間が使用されている。

表 4 気象体系の分類 ${ }^{32}$

\begin{tabular}{|c|c|c|c|c|}
\hline & 名 & 代声的灵さ（璃さ） & 代責的寿嗣時間 & 代茂的現象 \\
\hline 1 & large-scale & $3000 \mathrm{~km}(10 \mathrm{~km})$ & 1 力肙 & 落低父甠 \\
\hline $2 x$ & medium-scale & $1000 \mathrm{~km}(10 \mathrm{~km})$ & I過間 & 台 用 \\
\hline $3 x$ & meso-scale & $100 \mathrm{~km}(10 \mathrm{~km})$ & & 小低峖压 \\
\hline $4 t$ & topo-scale & $10 \mathrm{~km}(1 \mathrm{~km})$ & 1 時問 & 局地風 \\
\hline 5 & micro-scale & $1 \mathrm{~km}(100 \mathrm{~m})$ & 10 分䦓 & 大嘫流 \\
\hline
\end{tabular}

ここで，日本の建築物の耐風設計において，10 分間平 均風速を基準として設計速度圧を算定する方法は, 建築 基淮法では 2000 年の改正以降, 建築物荷重指針では 1981 年以降であり, それ以前では最大瞬間風速注2)を基淮に設 計速度圧が算定されていた。最大瞬間風速による算定は, 低層住宅のような小規模で固有振動数が低い建築物では 合理的であるが，高層建物における風外力の同時性が低 いといった規模効果や共振効果が考慮されていない等の 理由で現在のような基準に変遷してきた経緯がある ${ }^{33) 。}$ このように現在の日本の規基準では, 建築物の設計風速 に最大瞬間風速は考慮されていないが, 後述するガス卜 影響係数やピーク外圧係数を用いることで風荷重の最大 瞬間值が評価されている。なお, 海外の規基準では, 基準 風速に 3 秒間平均值を用いている $\mathrm{ASCE}^{34)}$ や $\mathrm{AS} / \mathrm{NZ}^{35}$ ) , 1 時間平均值を用いている $\mathrm{NRC}^{36}$ もあり，その平均化時間 は様々である。

\section{3 風洞実験や数值解析に基づく算定方法 \\ （1）構造骨組用風荷重}

建築基準法および建築物荷重指針における構造骨組用 風荷重の算定では, 10 分間平均風速に基づく速度圧とガ ス卜影響係数を用いて最大風荷重を評価している。この ガスト影響係数は強風中における建築物の最大変位と平 均変位の比として定義されている。

一方で, 風洞実験や数值流体計算の結果を用いた風荷 重の算定手法としては, 時刻歴応答解析と周波数応答解 析（スペクトルモーダル解析）の 2 つがあり, 時刻歴応 答解析を実施する場合, 風力, 变位, 加速度, 風荷重の最 大值は, 複数の時刻歴データ（設計風速の基準と同じく, 実スケールで 10 分間を 1 波形の時間単位とした時間解像 度 $0.1 \sim 0.2$ 秒程度の時刻歴波形とすることが多い）のア ンサンブル平均として算定される。なお, 建築物荷重指針 と同様の精度で評価するためには 5 回程度のアンサンブ

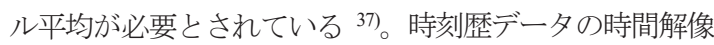
度については対象とする建築物の周期に対して十分小さ いものであるが，後述の外装材用風荷重を評価するため に実施される多点同時風圧測定の結果を用いることが日 本では多いため, 外装材用風荷重のピーク值の評価時間 によって決まってくる。

\section{（2）外装材用風荷重}

建築基準法および建築物荷重指針における外装材用風 荷重の算定においても，構造骨組み用風荷重の場合と同 様に, 設計風速の基準は 10 分間平均值であるが，ガス卜 影響係数ではなくピーク外圧係数を用いて最大風荷重を 評価している。これは風洞実験や数值流体計算でも同様 である。建築物荷重指針では, このピーク外圧係数の平均 化時間を $0.5 \sim 1.0$ 秒としている ${ }^{38)}$ 。風洞実験でも，実時 間で $0.5 \sim 1.0$ 秒程度が平均化時間となるようにサンプリ ング周波数に数倍の余裕をもたせて実時間で $0.1 \sim 0.2$ 秒 程度の時間解像度で測定を実施することが多い。

（3）仮設構造物の風荷重

技術指針 30)では，「2〜3 秒を考慮した瞬間風速に基づ いた風圧力を定める」とある。算定方法として, 再現期間 12 ケ月（1 年）に基づいた地域別の基準風速に，2３ 秒 の瞬間風速評価のためのピークファクター等に基づき算 出された, 地上高さ $\mathrm{Z}[\mathrm{m}]$ における瞬間風速分布係数を乗 じることで瞬間風速分布を推定する。

\section{4 課題や動向}

風洞実験では, 圧力測定模型製作上の制約があるため, 外装材用風荷重を算定するためのピーク外圧係数には, 外装材の受圧面積に応じた面平均值ではなく, TVL 法 ${ }^{39}$ に基づいた時間軸上の移動平均值が代用されている。こ の移動平均に用いる平均化時間には, 建築物荷重指針と 同じ $0.5 \sim 1.0$ 秒程度が用いられることが多いが，ピーク 值は, 平均化時間が短いほど大きくなる傾向があるため, 外装材の受圧面積に応じて適切な平均化時間を決定する 必要がある。しかし, ピーク外圧係数が作用する受圧面積 と平均化時間の関係については十分に明らかになってお

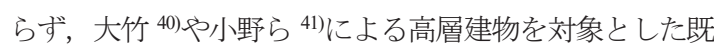
往の研究では, 従来の想定よりも平均化時間が小さくな るとの報告がある。

数值流体計算では, 高い解像度を有する空間離散点で 変動風圧の時刻歴データが得られるため, ピーク外圧係 数の算定過程では, 実際の外装材の受圧面積や形状に即 した空間平均処理が可能となる。図 4 に数值流体計算に よって算定したピーク外圧係数を受圧面積に応じて面平 均したピーク外圧係数の分布図を示す ${ }^{42)}$ 。図のような受 


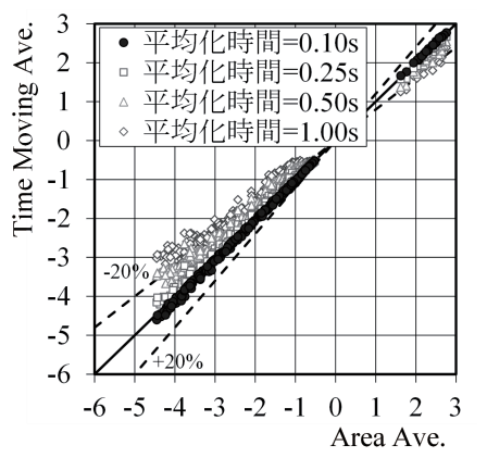

(a) 平均化面積 $A=1.0 \mathrm{~m}^{2}$

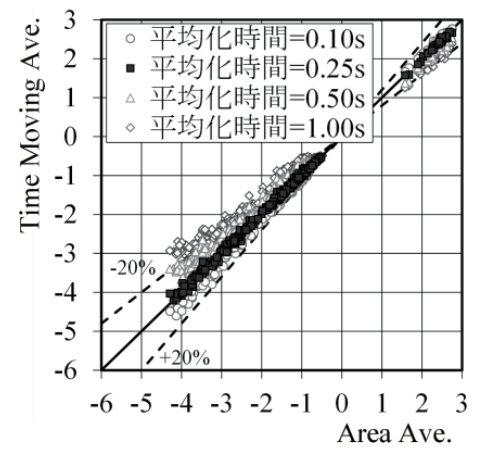

(b) 平均化面積 $A=4.0 \mathrm{~m}^{2}$

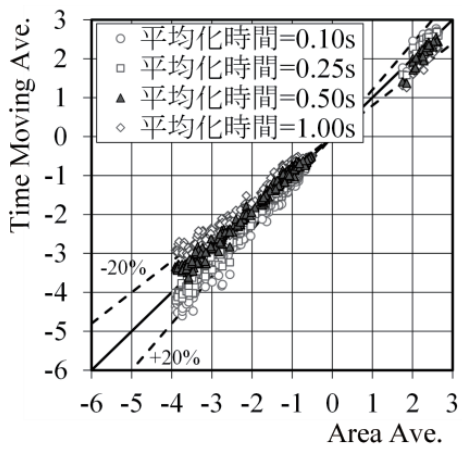

(c) 平均化面積 $A=16.0 \mathrm{~m}^{2}$

図 4 面平均によるピーク外圧係数と時間平均によるピーク外圧係数の比較 ${ }^{42)}$

圧面積に応じた面平均值と平均化時間が異なる時間平均 值を比較することで，外装材用風荷重の最大瞬間值を評 価するために最適な平均化時間と外装材の受圧面積の関 係を示すことができる。

仮設構造物については，技術指針では瞬間風速の平均 化時間を 2 3 秒とする根拠が明記されていないが, 建築 物の外装材用風荷重の算定に用いるピーク風力係数の平 均化時間との関係を見るとやや長い印象である。また, 短 期間の仮設物とはいえ, 基本風速の再現期間についても 安全性を考えると議論の余地があるように思われる。

\section{5. 大気污染物質の拡散と濃度}

大気中での污染物質の拡散と濃度の予測に関して, 主 に大気污染と臭気 (悪臭) の環境影響評価の観点から, 現 在の一般的な方法の状況をまとめる。

\section{1 大気污染}

(1) 評価する事象・目的・基準

大気污染物質の環境影響評価においては, 対象物質の 濃度を人の健康の保護や生活環境の保全の観点から評価 する。そのため, 大気污染防止法や環境基本法, 環境影響 評価法, その他条例等で規制物質およびその基準濃度, 評 価手続きなどが指定されている。

（2）濃度と風速の定義と主な予測・計測方法

対象とする物質にもよるが, 多くの濃度基準值が 1 時 間值や日平均值で示されている ${ }^{43)}$ 。また, 大気污染の環 境影響評価においては, ガウス分布型 (プルーム式やパフ 式）モデルなどの大気拡散式によって污染源周囲の污染 物質濃度が予測され, その際に風速・風向の情報が必要と

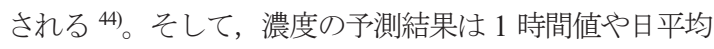
值, 年平均值などの観点から評価されることが多い。大気 中での污染物質濃度は, 様々なスケールでの乱流変動の
影響を受け，平均化時間を変えると時間平均值が大幅に 変化しうる。したがって, 特に毒性の強い物質であれば, 短時間曝露の影響も評価する必要があると考えられる。 しかし, 現状では, 1 時間より短い時間スケールにおける 大気污染物質への曝露による健康影響は, 各種基準等で 規制されるには至っていない。

上記のような状況により, 大気污染物質の濃度の予測 においては, 10 分や 1 時間程度の平均化時間に基づく, 平均風速や風向のデータが多く用いられている。また, そ れは気象観測所や大気測定局または評価対象地などにお ける一般的な気象観測によって取得される。つまり, 風 速・風向データは, 污染物質濃度予測時の背景あるいは境 界条件として用いられており, 1 時間以上の時間スケール での平均濃度が主な評価対象とされる限りは, 必ずしも それより短い平均化時間での風速のデータは直接的には 必要とされないのが現状である。ただし, 風洞実験や数值 流体解析を用いた污染物質拡散予測においては, 乱れ強 さなどの速度変動の統計量が必要であり, そのためには いわゆる瞬間風速のデータも間接的には用いられる。

5. 2 臭気 (悪臭)

(1) 評価する事象・目的・基準

臭気の環境影響評価においては, 悪臭物質の濃度や臭 気指数を地域住民の多くが日常生活において感知しない 程度であるかという観点から評価する。悪臭防止法やそ の他条例等で主たる悪臭物質およびその濃度または臭気 指数に関する規制值が指定されている ${ }^{45)}$

（2）濃度と風速の定義と主な予測・計測方法

悪臭物質の基準濃度には必ずしも明確に平均化時間が 示されていないことが多いが，臭気の環境影響評価関係 の資料では, 人の悪臭の知覚時間は数十秒 (30 秒) 程度 とされることが多い。また, 悪臭物質濃度の予測において 
も，大気污染と同様に大気拡散式が多く用いられる ${ }^{46 。}$ したがって, 平均風速や風向のデータとしては短くても 10 分程度の平均化時間に基づくものが用いられる。また, その観測方法なども大気污染と同様である。ただし，上記 のように濃度の平均化時間としては大気污染よりも短い ものが要求されることもあるため, その場合には大気拡 散式のパラメータ (拡散幅) を平均化時間に応じて補正す ることがある ${ }^{47) 。 ~}$

なお, 人の臭いの知覚時間については, より短い時間を 指摘する文献もある ${ }^{48)}$ 。臭いの知覚は臭いの成分を含む 空気を鼻腔に取り込むことに端を発するが，成人の安静 時の平均的な呼吸数は $12 \sim 20$ 回/分であり，つまり $3 \sim$ 5 秒に 1 回の頻度で呼吸（吸気と呼気のサイクル）を行 う。特に, 環境の空気を取り入れる吸気はその半分程度の 時間となるため, 鼻腔における臭いの平均化時間は数秒 程度であるとも考えられる。また, 被験者実験により人は 約 0.9 秒以内の時間で臭いの快・不快の判断が可能である ことを示した研究もある ${ }^{48)}$, 49)。このような短い時間スケ ールでの臭いの知覚が，その環境の継続的な質の評価に つながるか否かはまた異なる論点ではあると思われるが, 計測および予測手法が目指すべき平均化時間の一つとな りうると考えられる。

\section{6. 橋梁の耐風設計}

6. 1 評価する事象・目的・基準

橋梁の而風設計において風の影響は, 水平荷重として の風荷重と, 柔な橋, 部材に対する風による動的な影響の 形で考慮される。道路橋而風設計便覧 50)では, 風の作用 により構造物に発生する現象を, 静的空気力による変形・ 不安定現象といった静的現象と, 渦励振, ギャロッピン グ, フラッター, ガスト応答といった動的現象に分類して いる。これらの事象に対して, 橋の耐荷性能, 而久性能, 使用性が，橋の設計供用期間中に満足されるように設計 することが，耐風設計の基本方針となる ${ }^{51)}$ 。照査にあた って, 橋の応答は, 設計基淮類に与えられた荷重や, 風洞 実験, 数值流体解析, ガス卜応答解析などに基づいて求め られる。

\section{2 評価する際に用いる風速の定義}

標淮的な道路橋の耐風設計では, 10 分間の平均風速に 基づき，設計基本風速を定めている ${ }^{50-52)}$ 。10 分間という 評価時間を用いていることの根拠は明確ではないが，過 去の文献 ${ }^{53}$ において,「風速の観測方法の変せん」として, 気象庁の気象観測の平均風速値の平均化時間について記 述があることから，気象庁における扱いに準じたものと
推察される。

\section{3 課題や動向}

不規則な風速変動が原因で生じるガス卜応答の予測に は, 周波数領域の解析手法を用いるのが一般的で, その場 合は変動風速の特性は統計的に扱われ, 瞬間風速が解析 において陽に現れることはない。一方, より詳細な応答特 性等を明らかにすることを目的とした研究では，時間領 域でガス卜応答解析を実施することがあり，その場合は 変動風速がそのまま扱われる。ただし而風設計が特に重 要となる長大吊橋などにおいては, ガス卜応答において 支配的となる低次モードの固有振動数は数 10 秒程度とな ることから，応答に影響を及ぼすのは，「瞬間風速」と呼 ぶには平均化時間の長い, ゆっくりとした風速の変動で ある。

なお, 気流傾斜角は橋梁の動的安定性の発現に大きく 影響するため, それを正確に評価することは重要である。 自然風の鉛直方向の変動風速により生じる風の傾斜角に ついては, 振動の発達に要する時間の間に発現すると考 えられる平均傾斜角の最大值を設定するのが一つの考え 方であるが 52), その際に用いる平均化時間の決め方につ いては明確な指針は存在しておらず, それを含めて, 気流 傾斜角の適切な設定方法は現在でも研究課題となってい

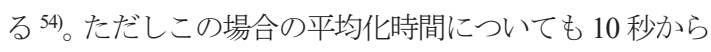
数 10 秒などとなり,「瞬間的」な気流傾斜角を対象とし たものではない。

以上のように，耐風性が特に重要となる吊形式の長大 橋梁においては, その固有振動数が低いこともあり, 通常 の意味での数秒を平均化時間とした瞬間風速が応答予測 に影響することは, 乱れの特性の違いによって剥離状況 が変化するといったこと以外にはない。一方で，「瞬間」 風速の捉え方をより広く取り，才なわちより長い周期の 「変動」風速の平均化時間をどのように設定するか, とい う形で設定した場合には，橋梁の動的現象における応答 の発達時間や固有振動数を念頭において平均化時間を考 えていく必要があり, 他の構造物や現象と同様, さらに議 論を深めていく必要があるといえる。

\section{7. スポーツおよび遊具}

構造物の而風設計や風環境などの風工学の代表的な夕 ーゲット以外にも着目し，陸上競技のトラック競技とエ ア遊具を取り上げについてまとめる。

7. 1 陸上競技のトラック競技

(1) 評価する事象・目的・基準

風により強く影響を受けるトラック競技の記録認定の 
ために，トラックのレーンのすぐ脇に風速計を設置し評 価している。使用される風速計, 設置場所, 計測時間など

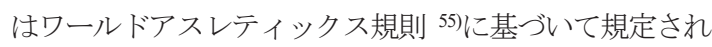
ている。

（2）風速の計測方法と評価時間

使用される風速計は, 世界記録認定の場合と, 日本記録 認定の場合で異なるが, 前者は非機械的 (超音波) 風向風 速計の使用が義務付けられているが，後者は機械的風向 風速計でも構わないとされている。

風速計設置位置は

・直走路の第 1 レーンに隣接したフィニッシュラインか

ら $50 \mathrm{~m}$ の地点

・測定面はトラックから $2 \mathrm{~m}$ 以上離してはならず, 高さは $1 \mathrm{~m} 220( \pm 50 \mathrm{~mm})$

と規定されている ${ }^{56)}$ 。

風速の評価時間は競技種目によって異なるが, $100 \mathrm{~m}$ 走 の場合，スターターの信号機の発射から 10 秒間を評価時 間として平均風速を算出する。計測結果は，小数第 2 位 が 0 でない限り， $0.1 \mathrm{~m} / \mathrm{s}$ 単位に繰り上げられる。公認協 議会の屋外記録は，風速が $+2.0 \mathrm{~m} / \mathrm{s}$ を超えた場合，参考記 録として区分される。これらは，Ward-Smith によれば数 多くの $100 \mathrm{~m}$ 走のデータを分析した結果に基いた規定と されている ${ }^{57)}$

\section{2 エア遊具}

(1) 評価する事象・目的・基準

遊園地やイベントで見かけるエア遊具に強風が作用, 横転し，事故が発生している ${ }^{58)}$ 。このような事故を受け て, 作用する風力 (風速) を安全性の観点から評価したガ イドラインが策定されている ${ }^{59)}$ 。

(2) 風速の計測方法と評価時間

前述のガイドラインでは，瞬間風速に基づいて 3 段階 の基準が設けられている。瞬間風速が $8 \mathrm{~m} / \mathrm{s}$ を超えた場 合「運営注意」, $10 \mathrm{~m} / \mathrm{s}$ を超えた場合「運営中断」という 基準である。風速計の設置および計測については記載さ れているものの, 使用する風速計の種別および評価時間 に関しては明確な基準はない。なお, 吉田らによる風洞実 験では ${ }^{60)}$, 瞬間風速 $10 \mathrm{~m} / \mathrm{s}$ を超えた際に被害が発生する 可能性があるとされている。

今回取り上げたトラック競技やエア遊具のほかにも, 主に種々のスポーツで風速を計測, 評価する場面がある。 風速の規定が存在するものの, 評価時間の根拠が明確で ないものもある。各種スポーツに影響する風速の評価時 間については議論の余地があるように思われる。

\section{8.まとめ}

本稿では，風工学に関連する各分野での評価に用いる 風速の考え方についてまとめた。各分野において評価に 用いる風速は, 評価する事象やその目的に応じて定めら れていることを示した。分野によっては瞬間風速を直接 取り扱わずに平均風速を介して求める手法が用いられる ことや, 瞬間風速の平均化時間が実験・観測機器の特性等 に依存しているような分野も見られた。計測機器の性能 や数值解析技術の向上に伴い, データ取得に関する制約 は少なりつつあるが，評価のための平均化時間の考え方 については各分野とも更なる検討が必要であると考えら れる。

注記

1) 建築基準法では設計速度圧の算定式が明示されてい るのみで，設計風速の算定式は明示されていないが， $\mathrm{Er} \times \mathrm{V}_{0}$ によって設計風速が算定できる。ここで, Er は 平均風速の高さ方向の分布を示す係数である。

2) 2007 年 12 月 4 日以降, 瞬間風速は 0.25 秒間隔で観測 される測定值を 3 秒間移動平均した值（測定值 12 個 の平均值) に変更された。それ以前は 0.25 秒間隔の観 測值がそのまま瞬間風速とされていた。

参考文献

1) 荒木啓司, 日比野有, 鈴木実,「列車運行と強風規制」, 日本風工学会誌, Vol.40, No.1, pp.10-16, (2015)

2）鉄道強風対策協議会，「風観測の手引き」，国土交通省， (2006)

3）島村誠，松沼政明，「強風警報システムの開発と実用 化」, JR East Technical Review, No.13, pp.36-43, (2005)

4) 余部事故技術調査委員会, 「余部事故技術調査委員会 報告書」，財団法人鉄道総合技術研究所，(1988)

5）公益財団法人鉄道総合技術研究所，「風速計の違いに よる最大瞬間風速の捉え方の違い,

https://www.rtri.or.jp/rd/division/rd46/rd4610/rd46100104. $h t m l,(2020$ 年 12 月 23 日閲覧)

6) 南雲洋介, 石原孟, 「空気力推定值の不確かさを考慮 した横風に対する鉄道車両の信頼性評価」, 風工学シ ンポジウム論文集，No.24，pp.361-366，(2016)

7) 今井俊昭, 島村泰介, 福原隆彰, 「2 地点の風速相関 を考慮した強風監視法の検討」, 鉄道総研報告, Vol.18, No.9, pp.5-10, (2004)

8) 荒木啓司, 福原隆彰, 島村泰介, 今井俊昭, 「数值解 析手法を用いた鉄道沿線における強風箇所の抽出方 
法」, 鉄道総研報告, Vol.24，No.5，pp.29-34，(2010）

9) 三須弥生, 石原孟, 「風観測と数值流体解析を利用し た運転規制区間内の強風発生頻度の予測」, 日本風工 学会論文集, Vol.37, No.1, pp.11-24, (2012)

10) 航空・鉄道事故調查委員会, 「鉄道事故調查報告書 (東 日本旅客鉄道株式会社 羽越線砂越駅～北余目駅間 列車脱線事故)」, (2008)

11）東日本旅客鉄道株式会社，「気象情報の活用による運 転規制方法の試行開始について」，(2008) https:/www.jreast.co.jp/press/2007_2/20080110.pdf ， (2020 年 12 月 23 日閲覧)

12）東海旅客鉄道株式会社，「在来線全線区へのレーダ雨 量を活用した運転規制の導入について」，(2018) https://jr-central.co.jp/news/release/_pdf/000036905.pdf , (2020 年 12 月 23 日閲覧)

13）西日本旅客鉄道株式会社，「局地的な大雨に対する さらなる安全性向上」, (2020)

https:/www.westjr.co.jp/press/article/items/200924_00_an zenseikoujyou.pdf, (2020 年 12 月 23 日閲覽)

14）村上 周三, 岩佐 義輝, 森川 泰成, 「居住者の日誌に よる風環境調査々評価尺度に関寸る研究一市街地低 層部における風の性状と風環境評価に関する研究-III 一」日本建築学会論文報告集, 第 325 号, pp.74-84 (1983)

15) 中村 修, 吉田 正昭, 横谷 恵二, 片桐 純治, 「市街 地の風の性状一主に風速の累積頻度からの検討一」, 第 9 回風工学シンポジウム論文集, pp.73-78,(1986)

16) 中村 修, 田村 幸雄, 日比一喜, 徐曉達, 楊 慶山, 宮下 康一，「都市域 320 地点の歩行者レベルの風観 測データに基づく風安全指標の提案」, 日本風工学会 論文集, 第148 号,pp.103-111, (2016)

17) 赤星 明紀, 猿川 明, 佐々木 亮治, 宮下 康一, 中村 修, 植松 康,「風の乱れの影響を考慮した風環境評価 指標に関する研究」, 日本風工学会論文集, 157 号, pp.113-130, (2018)

18) M. H. Melbourne, "Criteria for environmental wind conditions", J. Industrial Aerodynamics, 3(2/3), 241-249, (1978)

19) 藤井 邦雄, 営野 照雄, 「建築物周辺の気流に関する 調査研究 (その 2) 一市街地風の風観測システムにつ いて一, 清水建設研究所報, 第 32 号, pp.43-50, (1980)

20) 赤星 明紀, 猿川 明, 佐々木 亮治, 宮下 康一, 中村 修, 植松 康, 「風環境評価のための三杯型風速計と 超音波型風速計による統計量の差の検討」, 日本風工
学会論文集, 第 156 号, pp.91-99, (2018)

21）義江 龍一郎，富永 禎秀，伊藤 真二，岡田 創, 片岡 浩人, 喜々津 仁密, 佐々木 澄, 西村 宏昭, 野田 博, 林田 宏二, 宮下 康一, 山中 徹, 吉川 優, 「日最大 瞬間風速の超過確率に基づく風環境評価に用いるガ ストファクターの提案」, 日本風工学会論文集, 第 139 号, pp.29-39, (2014)

22) 本郷 剛, 中山 かほる,「風環境評価用ガストファク ターの提案」, 鹿島技術研究所年報, 第 51 号, pp.165-170, (2003)

23）木梨智子, 小野佳之, 片岡 浩人, 川口彰久, 「市 街地風環境の予測・評価技術」, 大林組技術研究所報, No. 69, pp. 1-8, (2005)

24）西村 宏昭, 高森 浩治,「ビル風評価のためのガスト ファクター--接近流の乱れ強さの影響」, GBRC, No. 105, pp. 27-32, (2002)

25) 赤林 伸一, 有波 裕貴, 「粒子画像流速測定法(PIV)に よる建物周辺気流に関する基礎的研究 その 1 高層 と中層の建物を対象とした屋外気流性状に関する PIV 測定結果」, 日本風工学会年次研究発表会梗概集, pp.107-108, (2017)

26）今野尚子, 田中英之, 大竹和夫, 土屋直也, 「LES による超々高層建築物周辺の風環境に関する検討」, 日本建築学会大会学術講演梗概集, pp.125-126, (2014)

27）菊本 英紀，大風 翼，池谷 直樹，富永 禎秀,「LES を 用いた単体建物モデル周辺気流における最大瞬間風 速の解析」, 日本風工学会年次研究発表会梗概集, pp.177-178, (2019)

28）日本建築学会，「建築物荷重指針・同解説（2015）」, (2015)

29）e-Gov 法令検索，「建築基準法」, https://elaws.egov.go.jp/document?lawid=325AC0000000201, (2021.01)

30）社団法人 仮設工業会, 「改定 風荷重に対寸る足場 の安全技術指針」,(1999)

31）岡内功, 伊藤學, 宮田利雄, 「而風構造」, 丸善, (1977)

32）日本気象協会関西本部，「瀬戸内海海象気象調查委員 会報告書」,(1973)

33）日本建築学会，「建築物荷重指針・同解説（1981）」, (1981)

34) American Society of Civil Engineers (ASCE), "Minimum design loads and Associated Criteria for buildings and other structures", (2016)

35) Standards Australian/Standards New Zealand (AS/NZS), 
"Australian/New Zealand Standard, Structural design actions, Part 2: Wind actions", (2011)

36) National Research Council (NRC), "National building code of Canada", (2010)

37）日本建築学会,「建築物荷重指針を活か寸設計資料 2」, (2017)

38）日本建築学会，「建築物荷重指針・同解説（1993）」, (1993)

39) Lawson, T. V., "Wind Effects on Buildings", Vol.1, 2, Applied Science Publishers, pp.192, (1980)

40) 大竹和夫，「高層建物の外装材用ピーク風圧係数に関 する研究 (その 2) ピーク風圧の空間的広がり」,日 本建築学会大会学術講演梗概集, pp.143-144,(2001)

41）小野佳之，田村哲郎，「三次元角柱のピーク負圧に関 する字空間平均評価の LES による検討」，日本風工 学会年次研究発表会梗概集, pp.189-190,(2013)

42）田中英之，大竹和夫，土屋直哉，今野尚子，「LES に よる低層建物の外装材用ピーク外圧係数に関する時 空間評価」，風工学シンポジウム論文集，Vol.24， pp.343-348, (2016)

43）環境省，「大気污染に係る環境基準」， https:/www.env.go.jp/kijun/taiki.html, (2021.1)

44) 近藤裕昭,「大気環境影響評価」, 日本気象学会, https://www.metsoc.jp/kyoikuhukyu/resume/Kondo.pdf , (2021.1)

45) 増田淳二,「㤟臭公害とにおい環境」，生活衛生, Vol. 50 No. 5, pp. 307-312, 2006

46) 増田淳二，「悪臭公害の評価方法」，生活衛生, Vol. 32 pp. 192-194, 1988

47）環境省，「廃棄物処理施設生活環境影響調査指針 資 料編 5. 悪臭関連」, https://www.env.go.jp/recycle/misc/facility_assess/mat05.p df, (2021.1)

48) Olofsson, "Time to smell: a cascade model of human olfactory perception based on response-time (RT) measurement”, Frontiers in Psychology, Vol. 5, Article 33, 2014

49) Wells, "Reaction-Times to Affects Accompanying Smell
Stimuli”, The American Journal of Psychology, Vol. 41, No. 1, pp. 83-86, 1929

50) 日本道路協会，「道路橋而風設計便覧（平成 19 年改訂 版)」,(2007.12)

51) 日本道路協会，「道路橋示方書・同解説，I 共通編（平 成 29 年)」, (2017.11)

52) 本州四国連絡橋公団,「本州四国連絡橋台風設計基準 (2001) ・ 同解説」, (2001.8)

53）土木学会・本州四国連絡橋技術調査委員会，「本州四 国連絡橋技術調査報告書，付属資料 1 而風設計指 針(1967)および同解説」,(1967.7)

54) 杉山 裕樹, 川㟝 雅和, 坂井 紀之, 内田 良始, 宮下 康一, 勝地 弘, 金 恵英, 八木 知己，「長大斜張橋主 桁の而風設計に係る気流傾斜角の検討」，風工学研究 論文集，第26 巻,pp.185-194, (2020. 11)

55) World Athletics, "Book of Rules (Book C : Competition, C2.1 - Technical Rules (1 November 2019))", https://www.worldathletics.org/aboutiaaf/documents/book-of-rules, (2021.1)

56）日本陸上競技連盟，「日本陸上競技連盟競技規則／第 3 部 ト ラック 競 技」 , https://www.jaaf.or.jp/pdf/about/rule/2020/p223_279.pdf, (2021.1)

57) A. J. Ward-Smith, "A mathematical analysis of the influence of adverse and favorable winds of sprinting", J. Biomechanics, Vol.18, No.5, pp.351-357, 1985

58）消費者庁，「エア遊具の事故防止について」，News Release (平成 28 年 3 月 31 日) , https://www.caa.go.jp/policies/policy/consumer_safety/rele ase/pdf/160331kouhyou_3.pdf(2021.1)

59）一般社団法人日本エア遊具安全普及協会，「JIPSA 安 全運営 の 10 ケ https://www.jipsa.org/images/2020/02/20200214_jipsa10k ajover4.pdf, (2021.1)

60) 吉田 昭仁, 栗橋 寿, 佐々木 信一, 田村 幸雄, 「工 ア遊具の風力特性および限界風速の推定」，平成 21 年度日本風工学会年次研究発表会・梗概集, pp.143144,2009 